\title{
Identifikasi Senyawa Aktif dan Toksisitas Hayati Ekstrak $N$ - Heksana, Etil Asetat dan Etanol Mikroalga Tetraselmis Chuii Secara Brine Shrimp Lethality Test (BSLT)
}

\author{
Identification of Active Compound and Biological Toxicity of Extract of n-Hexane, \\ Ethyl Acetate and Ethanol From Microalgae Tetraselmis chuii with Brine Shrimp \\ Lethality Test (BSLT)
}

\author{
Ni Wayan Sri Agustini \\ Pusat Penelitian Bioteknologi-LIPI \\ wayan_sa2002@yahoo.com
}

Riwayat Naskah:

Diterima 06,2017

Direvisi 07,2017

Disetujui 07,2017

\begin{abstract}
ABSTRAK. Tetraselmis chuii adalah salah satu jenis mikroalga yang termasuk ke dalam kelas Chlorophyceae, dan mempunyai prospek sebagai penghasil senyawa bioaktif yangbermanfaat sebagai antibakteri, antioksidan, antiinflamasi, antitumor, antikanker dan lain-lain. Uji potensi suatu senyawa bioaktif diantaranya dengan melakukan uji toksisitas hayati menggunakan metode Brine Shrimp Lethality Test (BSLT). Senyawa bioaktif diekstraksi menggunakan metode sokletasi, dengan berbagai tingkat kepolaran yaitu n-heksana (non polar), etil asetat (semi polar) dan etanol(polar). Uji toksisitas dilakukan terhadap larva udang Artemia salina Leach dengan menghitung nilai $\mathrm{LC}_{50}$. Identifikasi senyawa dengan menggunakan Kromatografi Gas Spektrofotometer Massa (KG-SM). Hasil penelitian menunjukkan bahwa toksisitas hayati dari ekstrak n-heksana, etil asetat dan etanol dengan nilai LC50 secara berturut-turut adalah 39,30 ppm (n-heksana); 38,53 ppm (etil asetat); 239,12ppm (etanol). Tahap selanjutnya ekstrak n-heksana dan etil asetat dilakukan fraksinasi dan penyederhanaan fraksi. Pada ekstrak n-heksana diperoleh 4 fraksi, sedangkan ekstrak etil asetat diperoleh 6 fraksi. Toksisitas hayati pada fraksi n-heksana adalah fraksi no 2 dengan nilai $\mathrm{LC}_{50}$ sebesar 32,61 ppm, mengandung Phytol 2 Hexadecen - 1 - ol 3,7,11,15 - tetramethyl dan 1,2 Benzendicarboxylic acid, mono (2 - ethylhexyl) ester sedangkan pada ekstrak etil asetat nilai $\mathrm{LC}_{50}$ tertinggi diperoleh dari fraksi no 1 yaitu 38,44 ppm, mengandung 1,2 Benzendicarboxylic acid, bis (2-ethylhexyl) ester. Berdasarkan hasil yang diperolehekstrak n-heksana dan etil asetat dari T. chuii bersifat toksik dan berpotensi sebagai salah satu alternatif obat antikanker alami.
\end{abstract}

Kata kunci :Tetraselmis chuii, ekstrak n-heksana, etil asetat, etanol, toksisitas hayati.

ABSTRACT. Tetraselmis chuii is Chlorophyceaemicroalgae class, and has a great prospect as producer of bioactive compound, as an antibacterial, antioxidant, anti-inflammatory, antitumor, anticancer and others. To assess potential of bioactive compound is by biological toxicity assay using Brine Shrimp Lethality Test (BSLT). Bioactive compounds were extracted by soxhletation with different degrees of polarity,n-hexane (non-polar), ethyl acetate (semi-polar) and ethanol (Polar). Toxicity tests conducted on shrimp larvae Artemia salina Leach to find out $\mathrm{LC}_{50}$ values. Identification of compound using Gas Chromatography Mass Spectrophotometer (GC-MS). The resultsof $\mathrm{LC}_{50}$ of extract $\mathrm{n}$-hexane, ethyl acetate and ethanol respectively are $39.30 \mathrm{ppm} 38.53 \mathrm{ppm} 239,12 \mathrm{ppm}$, respectively. The next stage, n-hexane and ethyl acetate extracts were fractionated. Four and 
six fractions were obtained from n-hexane sixand ethyl acetate, respectively Biological toxicity of n-hexane extract was tested at fraction number 2 with a value of the $\mathrm{LC}_{50}$ is $32.61 \mathrm{ppm}$, containing Phytol 2 - Hexadecen - 1 - ol 3,7,11,15 tetramethyl and 1.2 Benzendicarboxylic acid, mono (2 - ethylhexyl) ester, while ethyl acetate was tested at fraction number 1 with a value of LC50 is 38.44 ppm, containing 1.2 Benzendicarboxylic acid, bis (2-ethylhexyl) ester. Based on the results obtained, extract n-hexane and ethyl acetate from $T$. chuii are toxic and potential as natural anticancer drugs.

Keywords: Tetraselmis chuii, extract n-hexane, ethyl acetate, ethanol, biological toxicity.

\section{Pendahuluan}

Di Indonesia penggunaan obat herbal sebagai upaya kesehatan cenderung meningkat.Hal ini dikarenakan adanya isu back to nature. Masyarakat berasumsi bahwa bila digunakan dengan dosis yang benar dan tepat, obat herbal mempunyai efek samping relative kecil. Selain itu, obat herbal bisa memiliki lebih dari satu efek farmakologi (Katno, 2008).

Usaha penyembuhan umumnya relatif mahal dan memiliki efek samping yang besar. Hal tersebut mendorong untuk mencari senyawa-senyawa baru, dan senyawa-senyawa tersebut dapat ditingkatkan pemanfaatannya sebagai salah satu kandidat obat yang berkhasiat. Senyawa-senyawa toksik dapat diperoleh dari bakteri, tanaman, termasuk mikroalga. Tetraselmis chuii merupakan mikroalga dari golongan alga hijau kelas Chlorophyceae, dan mempunyai prospek sebagai salah satu alternatif penghasil senyawa bioaktif potensial. Mikroalga Tetraselmis chuii dipilih karena masih kurangnya informasi tentang uji toksisitas dari mikroalga tersebut dan mengingat kandungan mikroalga Tetraselmis chuii yaitu, protein 46,5\%, lemak 12,3\% dan karbohidrat 25\% (Tibbetts, 2015)

Salah satu metode untuk mendapatkan senyawa bioaktif yaitu dengan cara soxhletasi. Soxhletasi merupakan penyarian berkesinambungan, kandungan senyawa yang diperoleh tergantung pada tingkat kepolaran pelarut yang digunakan. Pelarut non polar seperti n-heksana akan melarutkan lemak, terpenoid, dan steroid, pelarut semi polar seperti etil asetat akan melarutkan protein, xanthon, flavonoid dan senyawa polifenol dan pelarut polar seperti etanol akan melarutkan senyawa seperti karbohidrat (Harbone, 1996).

Salah satu cara untuk mengetahui potensi suatu senyawa sebagai alternatif obat baru adalah dengan melakukan uji toksisitas hayati.Prinsip uji toksisitas adalah bahwa komponen bioaktif selalu bersifat toksik jika diberikan dengan dosis tinggi dan bersifat obat jika diberikan pada dosis rendah.Uji toksisitas dilakukan dengan metode BSLT (Brine Shrimp Lethality Test) yang merupakan uji pendahuluan untuk menentukan apakah suatu senyawa mempunyai kandungan bioaktif dan memiliki aktifitas farmakologi. Metode tersebut memiliki beberapa keunggulan, yaitu lebih cepat, murah, mudah, tidak memerlukan kondisi aseptis dan tingkat kepercayaan 95\%. Hewan uji yang digunakan adalah Artemia salina Leach (Meyer, et. al., 1982)

Toksisitas dari suatu ekstrak disebabkan oleh kandungan senyawa yang terdapat dalam bahan atau ekstrak tersebut, maka perlu dilakukan uji identifikasi senyawa dengan KG-SM (Kromatografi Gas - Spektrofotometer Massa). Berdasarkan uraian diatas, maka dilakukan penelitian uji tosisitas ekstrak Tetraselmis chuii dengan metode BSLT menggunakan larva udang Artemia salina Leach dan identifikasi senyawa dengan $\mathrm{KG}-\mathrm{SM}$.

\section{Bahan dan Metode}

\subsection{Bahan}

Natrium klorida, Kalium nitrat, kalium dihidrogen fosfat, Natrium bikarbonat, Magnesium klorida, Kalsium klorida (0,2g/L), kalium klorida), Magnesium sulfat, Seng Sulfat, asam Borat, Mangan Klorida, Tembaga Sulfat, Ammonium Molibdat, $n$ Heksana, Etil Asetat, Etanol dan Air laut sintetik

\subsection{Alat}

Sentrifuga (Hitachi CT6EL), Spektrofotometer UV-Visible (Hitachi U 3900H), Mikroskop(NikonJapan), Neraca analitik (Precisa 303 Adam Scout No.SC 6010, USA), Oven (Haraeus), Vortex(Thermolyte), Rotary Evaporator (BUCHI Rotavapor R-200), desikator (Iwaki, Duraner), magnetik Stirrer (Thermolyne), mikropipet (Eppendorf), Spuit, Botolvial, Pipet Volume, Selang 
Aerasi, Cawan Penguap, Alumunium Foil, Kotak Penetasan, Kaca Pembesar (LUP), Lampu TL 18 watt Lampu UV dan alat-alat gelas (pyrex).

\subsection{Metode}

\subsubsection{Kultivasi Mikroalga Tetraselmis chuii}

Tetraselmis chuii yang digunakan berasal dari Balai Besar Pengembangan Air Payau, Jepara. T. chuii dikultivasi dalam medium Johnson yang telah dimodifikasi yang terdiri dari $\mathrm{NaCl}(27 \mathrm{~g} / \mathrm{L}), \mathrm{MgSO}_{4}$. $7 \mathrm{H}_{2} \mathrm{O}(0,5 \mathrm{~g} / \mathrm{L}), \mathrm{MgCl}_{2}(1,5 \mathrm{~g} / \mathrm{L}), \mathrm{CaCl}_{2} 4 \mathrm{H}_{2} \mathrm{O}(0,2 \mathrm{~g} / \mathrm{L})$, $\mathrm{KNO}_{3} \quad(1 \mathrm{~g} / \mathrm{L}), \quad \mathrm{KH}_{2} \mathrm{PO}_{4} \quad(0,035 \mathrm{~g} / \mathrm{L}), \quad \mathrm{NaHCO}_{3}$ $(0,043 \mathrm{~g} / \mathrm{L}), \mathrm{Lar} . \mathrm{Fe}+$ EDTA $(1 \mathrm{ml}) . T$. chuiidikultivasi dalam botol ukuran 2 liter, $\mathrm{pH}$ awal 7,0, intensitas cahaya 2500 lux dan sistem aerasi secara terus menerus dengan menggunakan Blower. Kepadatan sel diukur dengan metoda Turbidimetri menggunakan spektrofotometer pada panjang gelombang $680 \mathrm{~nm}$. T. chuii dipanen pada fase stasioner awal dengan cara disentrifus kecepatan 4000rpm selama 15 menit. Biomassa yang didapat kemudian dikeringkan dalam oven pada suhu $50^{\circ} \mathrm{C}$.

\subsubsection{Skrining Fitokimia Biomassa T. chuii}

\subsubsection{Alkaloid}

Biomassa ditimbang $100 \mathrm{mg}$ dan dilembabkan dengan $5 \mathrm{ml}$ ammonia 30\% digerus dalam mortar, kemudian ditambahkan $20 \mathrm{ml}$ kloroform. Setelah itu, campuran tersebut disaring danfiltrat berupa larutan organik diambil (Larutan A/Lar. A). Lar. A diambil $1 \mathrm{ml}$ dan ditambahkan dengan $10 \mathrm{ml}$ larutan $\mathrm{HCl}$ 1:10 lalu dikocok hingga homogen dan diambil larutan bagian atasnya (Larutan B/Lar. B). Lar.A ditambahkan 2-3 tetes reagen Dragendorff dan Lar.B ditambahkan 2-3 tetes reagen Mayer.Jika pada Lar.A terbentuk endapan jingga dan pada Lar.B terbentuk endapan kekuning-kuningan, maka menunjukkan adanya alkaloid (Indrayani, et al., 2006).

\subsubsection{Flavonoid}

Biomassa ditimbang sebanyak $100 \mathrm{mg}$ dan ditambahkan $100 \mathrm{ml}$ air panas, didihkan selama 5 menit, disaring dengan kertas saring hingga diperoleh filtrat yang akan digunakan sebagai larutan percobaan. Sebanyak $5 \mathrm{ml}$ filtrat ditambahkan dengan serbuk atau lempeng magnesium, setelah itu ditambahkan $1 \mathrm{ml} \mathrm{HCl} \mathrm{dan}$ amil alkohol, kocok kuat dan biarkan memisah. Jika terbentuk warna jingga pada lapisan amil alkohol maka flavonoid positif (Indrayani, et al., 2006)

\subsubsection{Saponin}

Uji saponin dengan menggunakan metode Forth. Biomassa ditimbang sebanyak $100 \mathrm{mg}$ dan ditambahkan $100 \mathrm{ml}$ air panas, didihkan selama 5 menit, disaring dengan kertas saring hingga diperoleh filtrat yang akan digunakan sebagai larutan percobaan. Setelah itu, diambil $10 \mathrm{ml}$ dan dimasukan kedalam tabung reaksi, lalu dikocok secara vertikal selama 10 detik kemudian didiamkan selama 10 menit akan terbentuk busa yang stabil menunjukan adanya senyawa golongan saponin, jika ditambahkan 1 tetes $\mathrm{HCl} 1 \%$ busa tetap stabil. (Setyorini et.al., 2008)

\subsubsection{Kuinon}

Biomassa ditimbang sebanyak $100 \mathrm{mg}$ dan ditambahkan $100 \mathrm{ml}$ air panas, didihkan selama 5 menit, disaring dengan kertas saring hingga diperoleh filtrat yang akan digunakan sebagai larutan percobaan. Setelah itu, diambil $5 \mathrm{ml}$ dari dan dimasukan kedalam tabung reaksi kemudian ditambahkan beberapa tetes larutan $\mathrm{NaOH} 1 \mathrm{~N}$ dan akan terbentuk warna merah intensif menunjukan adanya senyawa golongan kuinon (Prasetyorini, et al., 2011)

\subsubsection{Triterpenoid}

Biomassa ditimbang sebanyak $100 \mathrm{mg}$, kemudian dimaserasi $20 \mathrm{ml}$ dengan Eter selama 2 jam (didalam wadah dengan penutup rapat), kemudian disaring dan diambil filtratnya. Setelah itu, filtrat diuapkan dalam cawan penguap hingga diperoleh residu dan ditambahkan 2 tetes asam asetat anhidrat dan 1 tetes $\mathrm{H}_{2} \mathrm{SO}_{4}$. Terbentuknya warna hijau atau merah menunjukan adanya senyawa steroid dan triterpenoid (Isnawati, et al., 2008)

\subsubsection{Kumarin}

Biomassa ditimbang sebanyak $100 \mathrm{mg}$, ditambahkan $10 \mathrm{ml}$ pelarut kloroform dan dipanaskan selama 20 menit. Setelah dingin disaring, dan filtrat diuapkan dengan cawan penguap sampai kering. Residunya ditambahkan air panas sebanyak $10 \mathrm{ml}$, setelah dingin tambahkan 0,5 ml larutan ammonia $\mathrm{NH}_{4} \mathrm{OH} 10 \%$, amati dibawah sinar lampu ultraviolet, maka akan terjadi flouresensi warna kuning kehijauan atau kebiruan 
yang menunjukan adanya senyawa golongan kumarin (Isnawati, et al., 2008)

\subsubsection{Ekstraksi Biomassa T. chuii dengan metode soxhletasi}

Sebanyak 20 gr biomassa kering diekstraksi dengan cara soxhletasi.Pelarut yang digunakan secara berturut-turut, diawali dengan n-heksana, etil asetat dan etanol. Masing-masing pelarut diekstraksi selama 7 jam. Hasil ekstraksi dari ekstrak $n$-heksana, etil asetat dan etanol kemudian diuapkan dengan menggunakan rotary evaporator sampai pekat.

\subsection{Uji toksisitas hayati (Meyer, et al. 1982).}

\subsubsection{Penetasan Telur Artemia salina Leach}

Kurang lebih 20 mg telur Artemia salina Leach dimasukan kedalam bejana penetas yang telah berisi air laut sintetik dan disinari dengan lampu TL 18 Watt. Setelah 24 jam telur yang menetas menjadi naupilii dan dipindahkan ketempat lain. 24 jam kemudian naupilii tersebut sudah dapat digunakan sebagai hewan uji.

\subsubsection{Pembuatan Larutan Uji}

Konsentrasi larutan uji yang dibuat adalah 1000 ppm, 100 ppm dan 10 ppm, masing - masing dengan tiga kali pengulangan, serta 1 vial untuk kontrol positif. Masing-masing ekstrak dibuat larutan induk, sebanyak $50 \mathrm{mg}$ ekstrak dilarutkan dengan $5 \mathrm{ml}$ pelarut yang sesuai.Jika sampel sukar larut, tambahkan dimetil sulfoksida (DMSO) 1\% sebanyak 10-50 $\mu \mathrm{l}$.

\subsubsection{Pelaksanaan Uji Toksisitas Terhadap Artemia salina L}

Larutan uji $n$-heksana, etil asetat dan etanol dipipet berturut - turut $500 \mu \mathrm{l}, 50 \mu \mathrm{l}$ dan $5 \mu \mathrm{l}$ yang masing - masing dimasukan ke dalam vial kemudian diuapkan sampai kering. Setelah itu, tambahkan sebanyak $3 \mathrm{ml}$ air laut dan diaduk hingga homogen, kemudian masukkan 10 ekor naupilii, dan tambahkan air laut sampai $5 \mathrm{ml}$. Untuk setiap konsentrasi lakukan tiga kali pengulangan. Pengamatan dilakukan setelah 24 jam dengan menghitung jumlah larva yang mati dan hidup.

\subsubsection{Perhitungan}

3.1.4.1. Pengukuran mortalitas larva Artemia salina Leach dihitung dengan rumus sebagai berikut:

$$
\text { Mortalita }(\%)=\text { Akumulasi mati } \times 100 \%
$$
Akumulasi mati+Akumulasi hidup

3.1.4.2. Menghitung $L C_{50}$ dengan menggunakan regresi linier. $Y=a+b x$. Nilai $L C_{50}$ pada uji toksisitas adalah konsentrasi larutan uji yang dapat menyebabkan kematian pada $50 \%$ hewan percobaan. Perhitungan $L_{50}$ menggunakan persamaan regresi antara log D sebagai sumbu $x$ dan \% sebagai sumbu $y$.

\subsection{Fraksinasi dan Penyederhanaan Fraksi Ekstrak $n$-Heksana dan Etil Asetat dengan Kromatografi Kolom.}

Fraksinasi dengan kromatografi kolom bertujuan untuk mendapatkan fraksi yang mengandung senyawa lebih sederhana. Ekstrak $n$-heksana dan etil asetat difraksinasi dengan kromatografi kolom secara isokratik menggunakan fase gerak yang telah dipilih. Fase diam yang digunakan adalah silika gel 60. Setiap fraksi yang diperoleh dari hasil kromatografi kolom dilakukan KLT menggunakan lempeng silika gel $\mathrm{GF}_{254}$. Setiap fraksi yang memberikan profilbercak yang sama digabung menjadi satu fraksi. Setelah itu, hasil penggabungan fraksi diuji kembali toksisitas hayatinya

\subsection{Identifikasi senyawa dengan $K G-S M$}

Identifikasi senyawa dilakukan terhadap fraksi 1 etil asetat dan fraksi 2 n-heksana. Instrumen yang digunakan adalah Agilent 19091S-436, kolom HP$5 \mathrm{~ms}, \quad 0.25 \mathrm{~mm}$ diameter id, panjang $60 \mathrm{~mm}$, ketebalan film $0.25 \mu \mathrm{m}$ )volume injeksi: $1 \mu \mathrm{l}$, temperatur inlet: $290^{\circ} \mathrm{C}$, temperatur AUX: $290^{\circ} \mathrm{C}$, temperatur program: $70^{\circ} \mathrm{C}$ ( 15 menit) $-290^{\circ}(25$ menit), mode aliran gas : konstan dan gas pembawa: Helium.

\section{Hasil dan Pembahasan}

\subsection{Hasil Uji Fitokimia}

Berdasarkan hasil skrining fitokimia terhadap biomasa T. chuii, didapat hasil yang positif terhadap senyawa steroid dan kumarin (Tabel 1).Kedua senyawa tersebut yang diduga memiliki toksisitas terhadap larva udang Artemia salina Leach. Steroid adalah senyawa triterpen yang senyawa dasarnya terdiri dari cincin siklopentana perhidrofenantren 
(Lednicer, 2011).Sedangkan kumarin adalah suatu senyawa fenol yang memiliki aktifitas biologis diantaranya sebagai antikoagulan darah dan menghambat aktifitas zat karsinogenik (Harbone, 1987). Senyawa steroid dan kumarin dapat berfungsi sebagai racun perut dengan mekanisme mengganggu alat pencernaan dari larva udang Artemia salina L. Senyawa ini juga dapat menghambat reseptor perasa pada daerah mulut larva udang Artemia salina L yang mengakibatkan larva udang Artemia salina L gagal dalam mendapatkan stimulus rasa dan tidak mampu mengenali makanannya sehingga larva udang Artemia salina L akan mati kelaparan (De Padua et.al., 1999).

Tabel 1.

Hasil uji fitokimia biomasa T. chuii

\begin{tabular}{cc}
\hline Golongan Senyawa & Hasil \\
\hline Alkaloid & - \\
Flavonoid & - \\
Saponin & - \\
Kumarin & + \\
Steroid & + \\
Kuinon & - \\
\hline
\end{tabular}

\subsection{Ekstraksi Biomassa T. chuii secara Sokhletasi}

Ekstraksi biomassa T. chuii dilakukan dengan cara sokhletasi, dengan proses pemanasan zat aktif yang terkandung dalam biomassa dari mikroalga $T$. chuii dapat tersari secara sempurna, dan pelarut yang digunakan lebih sedikit serta proses isolasi yang lebih cepat. Pada penelitian ini ekstraksi dilakukan dengan menggunakan 3 pelarut yang berbeda, diawali dengan pelarutn-heksana (non polar), etil asetat (semi polar), dan etanol (polar).Berdasarkan literatur, pelarut non polar ( $n$ heksana) mampu mengekstrak senyawa yang larut dalam pelarut non polar seperti steroid, asam lemak, terpenoid, karotenoid. Pelarut semi polar (etil asetat) mampu mengekstrak senyawa yang larut dalam pelarut semi polar seperti polifenol, alkaloid, kumarin dan flavonoid, sedangkan pelarut polar (etanol) mampu mengekstrak senyawa yang larut dalam pelarut polar seperti komponen fenolik, glikosida, saponin dan tanin (Redja, 1982).

Berdasarkan studi yang telah dilakukan, ekstrak kering yang diperoleh dari masing-masing pelarut jumlahnya berbeda-beda. Bobot ekstrak yang diperoleh seperti terlihat pada Tabel 2. Hasil pengeringan ekstrak $n$-heksana sebesar 0,196 gram, etil asetat 0,354 gram dan etanol 0,737 gram. Persentase rendemen ekstrak menunjukan jumlah senyawa yang tersari dari masing-masing pelarut dengan jumlah biomassa mikroalga $T$. chuii. Rendemen tertinggi ditunjukkan oleh pelarut etanol yaitu 3,685 \% dan terendah dihasilkan oleh pelarut n-heksana yaitu 0,98\%. Tingginya nilai rendemen pada etanol menunjukkan bahwa pada biomasa T.chuii mengandung banyak senyawa polar (Tabel 2).

\subsection{Uji toksisitas secara Brine Shrimp Lethality Test (BSLT)}

Hasil uji toksisitas yang dilakukan dengan metode BSLT mengacu pada penelitianMeyeret all (1982), dimana Brine Shrimp Lethality Test (BSLT) merupakan pengujian awal untuk menentukan apakah suatu senyawa mempunyai kandungan bioaktif. Selain itu metode ini juga mudah dikerjakan, murah, cepat dan akurat.Penggunaan larva udang Artemia salina Leach sebagai hewan uji karena identik dengan sel kanker (Meyer, et al., 1982).Oleh karena itu, jika ekstrak atau senyawa yang digunakan memiliki aktivitas toksik yang tinggi maka ekstrak atau senyawa tersebut dapat berpotensi sebagai obat dimasa yang akan datang. Suatu zat dikatakan aktif atau toksik, bila nilai $\mathrm{LC}_{50}<$ 1000 ppm.

Pada Tabel 3 terlihat, setiap peningkatan konsentrasi ekstrak terjadi kenaikan tingkat mortalitas dari larva udang. Ini menunjukkan bahwa, semakin tinggi konsentrasi suatu zat yang diberikan, semakin besar pula jumlah larva udang yang mati. Hal ini berarti, semakin tinggi konsentrasi yang diberikan semakin besar pula keracunan yang ditimbulkan. Tingkat mortalitas yang paling tinggi terjadi pada konsentrasi 1000 ppm.

Pada Tabel 3 juga dapat dilihat, ekstraknheksana menyebabkan kematian 50\% pada konsentrasi 100 dan 1000 ppm yaitu dengan persentase kematian sebesar $63,16 \%$ dan 84,84 . 
Halaman | 13

Tabel 2.

Hasil ekstraksi biomasaT. chuii

\begin{tabular}{cccccc}
\hline No & Jenis Pelarut & Hasil Sokhletasi (m) & Hasil Evaporasi (ml) & HasilPengeringan (g) & Rendemen Ekstrak (\%) \\
\hline 1 & $n$-heksana & 511 & 4 & 0,196 & 0,98 \\
2 & Etil Asetat & 630 & 6 & 0,354 & 1,77 \\
3 & Etanol & 473 & 27 & 0,737 & 3,685 \\
\hline
\end{tabular}

Ekstrak etil asetat menyebabkan kematian 50\% pada konsentrasi 100 dan 1000 ppm dengan persentasi kematian sebesar $74,42 \%$ dan $95,16 \%$ dan ekstrak etanol menyebabkan kematian 50\% pada konsentrasi 1000 ppm yaitu 81,58\%. Nilai $\mathrm{LC}_{50}$

yang ditunjukkan oleh ekstrak etil asetat sebesar 38,53 ppm dan ekstrak $n$-heksan sebesar 39,30 ppm, sedangkan pada ekstrak etanol menunjukan nilai LC $_{50}$ yang lebih besar yaitu sebesar 239,38 ppm. Berdasarkan studi ini, ekstrak n-heksan dan etil asetat memiliki toksisitas yang lebih tinggi dibandingkan dengan ekstrak etanol. Tahap selanjutnya untuk mendapatkan ekstrak yang lebih murni dilakukan fraksinasi dengan kromatografi kolom terhadap n-heksana dan etil asetat.

Tabel 3.

Hasil ujitoksisitas hayati ekstrak n-heksana, etil asetat dan etanoldari biomasa T. chuii

\begin{tabular}{ccc}
\hline Fraksi & Vial & Bobot ekstrak (mg) \\
\hline F1 & 2 & 90,7 \\
F2 & 3 & 75,5 \\
F3 & $4-5$ & 78,4 \\
F4 & 6 & 74,3 \\
F5 & $7-15$ & 67,2 \\
F6 & $16-69$ & 62,1 \\
\hline
\end{tabular}

Berdasarkan hasil nilai $\mathrm{LC}_{50}$ dan uji fitokimia, senyawa kumarin dan steroid yang terdapat dalam mikroalga $T$. chuii memiliki peran dalam tingkat toksisitas $\left(\mathrm{LC}_{50}\right)$ terhadap larva udang Artemia salina Leach. Senyawa kumarin dan steroid merupakan metabolit sekunder yang mudah larut dalam pelarut non polar maupun semi polar, yang menyebabkan nilai $\mathrm{LC}_{50}$ pada n-heksan dan etil asetat lebih kecil dibandingkan pada ekstrak etanol yang merupakan pelarut polar. Carballo et.al., (2002)menyatakan bahwa terdapat hubungan yang kuat antara sitotoksisitas dan letalitas larva Artemia salina leach. Oleh karena itu, apabila harga $\mathrm{LC}_{50}$ suatu ekstrak bersifat toksik berdasarkan metode BSLT, maka ekstrak tersebut dapat dikembangkan sebagai obat antikanker.

3.4. Kromatografi Kolom dan Penyederhanaan Fraksiekstrak n-heksana dan etil asetat
Penyederhanaan fraksi dilakukan bertujuan agar diperoleh senyawa yang lebih murni. Fraksinasi dilakukan pada ekstrak $n$-heksana dan etil asetat yang memiliki nilai $\mathrm{LC}_{50}$ paling toksik terhadap larva udang Artemia salina Leach. Ekstrak $n$-heksana dan etil asetat difraksinasi menggunakan kromatografi kolom dengan eluen untuk fraksi $n$ heksana yaitu $n$-heksana : etil asetat (1:1) dan untuk fraksi etil asetat yaituetilasetat : $n$-heksana (4:5). Fraksinasi dilakukan hingga semua senyawa yang terdapat didalam ekstrak $n$-heksana dan etil asetat terpisah secara sempurna

Fraksinasi ekstrak $n$-heksana menghasilkan 25 fraksi yang masing-masing sebanyak $5 \mathrm{ml}$. Hasil fraksinasi kemudian dilakukan penyederhanaan fraksi, berdasarkan nilai Rf yang sama maka diperoleh 4 fraksi (Tabel 4). Sedangkan fraksinasi ekstrak etil asetat mendapatkan 69 fraksi, setelah dilakukan penyederhanaan fraksi diperoleh sebanyak 6 fraksi (Tabel 5).

Tabel 4.

Hasil penyederhanaan fraksi ekstrak $n$-heksana dari mikroalga T.chuii

\begin{tabular}{ccc}
\hline Fraksi & Vial & Bobot ekstrak (mg) \\
\hline F1 & 2 & 70,6 \\
F2 & 3 & 74,8 \\
F3 & 4 & 65,9 \\
F4 & $5-25$ & 57,1 \\
\hline
\end{tabular}

Tabel 5

Hasil penyederhanaan fraksi etil asetat dari mikroalga T. Chuii

\begin{tabular}{|c|c|c|c|c|}
\hline Uii & & & & \\
\hline To & Ekstrak & Konsentrasi & Kematian (\%) & $\mathrm{LC}_{50}(\mathrm{bpj})$ \\
\hline sit & & 1000 & 84,85 & \\
\hline as & $n$-heksana & 100 & 63,16 & 39,30 \\
\hline $\mathrm{Ha}$ & & 10 & 33,33 & \\
\hline$y a$ & & 1000 & 95,16 & \\
\hline$t i$ & etil asetat & $\begin{array}{l}100 \\
10 \\
1000\end{array}$ & $\begin{array}{l}74,42 \\
24,39 \\
81,58\end{array}$ & 38,53 \\
\hline$S L$ & Etanol & 100 & 20.00 & 239,38 \\
\hline T) & & 10 & 4,81 & \\
\hline
\end{tabular}

rhadap Hasil Dari Penyederhanaan Fraksi 
Citation:Agustini, Ni Wayan Sri (2017) Identifikasi Senyawa Aktif dan Toksisitas Hayati Ekstrak $N$-Heksana, Etil Asetat dan Etanol Mikroalga Tetraselmis Chuii Secara Brine Shrimp Lethality Test (BSLT) Warta IHP, 34(1),8-17

Hasil uji toksisitas fraksi $n$-heksana, menunjukan bahwa fraksi 1 menyebabkan kematian 50\% pada konsentrasi 10 ppm hingga $100 \mathrm{ppm}$ dengan persentasi kematian sebesar $23,08 \%$ hingga $51,11 \%$ dengan nilai $\mathrm{LC}_{50}$ sebesar 67,09 ppm, fraksi 2 menyebabkan kematian 50\% pada konsentrasi 10 ppm hingga 100 ppm yaitu dengan persentasi kematian sebesar 31,11\% hingga70\% dengan nilai $\mathrm{LC}_{50}$ sebesar 32,61 ppm, fraksi 3 menyebabkan kematian $50 \%$ pada konsentrasi 100 ppm hingga 1000 ppm yaitu dengan persentasi kematian sebesar 45,83\% hingga $97 \%$ dengan nilai $\mathrm{LC}_{50}$ ebesar 78,07 ppm, sedangkan fraksi 4 menyebabkan kematian 50\% pada konsentrasi 100 ppm hingga 1000 ppm yaitu dengan persentasi kematian sebesar 44,44\% hingga59,6774\% dengan nilai $\mathrm{LC}_{50}$ sebesar 255,12 ppm. Nilai $\mathrm{LC}_{50}$ yang dihasilkan dari semua fraksi lebih kecil dari 1000 ppm, hal ini meunjukkan bahwa semua fraksi memiliki efek toksisitas terhadap Artemia salina Leach. Urutan hasil uji toksisitas terhadap fraksi n-heksana yaitu fraksi $2>$ fraksi $1>$ fraksi 3 lalu fraksi 4 (Tabel 6).Berdasarkan hasil uji toksisitas terhadap fraksi, maka hanya fraksi 2 yang dilanjutkan untuk dilakukan analisa KG-SM untuk mengidentifikasi jenis atau golongan senyawa kimia.

Tabel 6.

Hasil uji toksisitas hayati pada fraksi $n$-heksana

\begin{tabular}{|c|c|c|c|c|}
\hline Ekstrak & Fraksi & Kons & $\begin{array}{c}\text { Kematian } \\
(\%)\end{array}$ & $\mathrm{LC}_{50}(\mathrm{bpj})$ \\
\hline \multirow{12}{*}{$\begin{array}{c}\text { n- } \\
\text { heksana }\end{array}$} & 1 & 1000 & 94,34 & \multirow{3}{*}{67,09} \\
\hline & & 100 & 51,11 & \\
\hline & \multirow{4}{*}{2} & 10 & 23,08 & \\
\hline & & 1000 & 96,92 & \multirow{3}{*}{32,61} \\
\hline & & 100 & 70 & \\
\hline & & 10 & 31.11 & \\
\hline & \multirow[t]{2}{*}{3} & 1000 & 97 & \multirow{3}{*}{78,07} \\
\hline & & 100 & 45,83 & \\
\hline & \multirow{4}{*}{4} & 10 & 19,64 & \\
\hline & & 1000 & 59,68 & \multirow{3}{*}{255,12} \\
\hline & & 100 & 44,44 & \\
\hline & & 10 & 24,29 & \\
\hline
\end{tabular}

Hasil uji toksisitas terhadap fraksi etil asetat pada Tabel 7, menunjukan bahwa fraksi 1 menyebabkan kematian 50\% pada konsentrasi 10 hingga 100 ppm yaitu dengan persentasi kematian sebesar 28,57\% hingga 65,91\%, fraksi 2 menyebabkan kematian $50 \%$ pada konsentrasi 10 hingga 100 ppm yaitu dengan persentasi kematian sebesar $12,19 \%$ hingga $68,57 \%$, fraksi 3 menyebabkan kematian 50\% pada konsentrasi 100 hingga 1000 ppm yaitu dengan persentasi kematian sebesar 38,46\% hingga 66\%, fraksi 4 menyebabkan kematian 50\% pada konsentrasi 100 hingga 1000 ppm yaitu dengan persentasi kematian sebesar $49,12 \%$ hingga $75,86 \%$, fraksi 5 menyebabkan kematian 50\% pada konsentrasi 100 ppm hingga 1000 ppm yaitu dengan persentasi kematian sebesar 45,31\% hingga 71,19\%, fraksi 6 menyebabkan kematian $50 \%$ pada konsentrasi 10 ppm hingga 100 ppm yaitu dengan persentasi kematian sebesar 20\% hingga51,92 \%.

Pada Tabel 7 juga terlihat nilai $L_{50}$ yang dihasilkan dari semua fraksi lebih kecil daripada $1000 \mathrm{ppm}$, dan urutan hasil uji toksisitasnya yaitu fraksi $1>$ fraksi $2>$ fraksi $6>$ fraksi $4>$ fraksi $5>$ fraksi 3. Oleh karena itu, fraksi 1 dilanjutkan untuk dilakukan analisa KG-SM untuk diidentifikasi jenis atau golongan senyawa kimia.

Tabel 7.

\begin{tabular}{|c|c|c|c|c|}
\hline Ekstrak & Fraksi & Kons & $\begin{array}{c}\text { Kematian } \\
(\%)\end{array}$ & $\mathrm{LC}_{50}(\mathrm{bpj})$ \\
\hline \multirow{18}{*}{ Eil aseat } & 1 & 1000 & 100 & \multirow{3}{*}{38,44} \\
\hline & & 100 & 65,91 & \\
\hline & & 10 & 28,57 & \\
\hline & 2 & 1000 & 100 & \multirow{3}{*}{58,39} \\
\hline & & 100 & 67,57 & \\
\hline & & 10 & 12,19 & \\
\hline & 3 & 1000 & 66 & \multirow{3}{*}{269,90} \\
\hline & & 100 & 38,46 & \\
\hline & & 10 & 8,06 & \\
\hline & 4 & 1000 & 75,86 & \multirow{3}{*}{108,86} \\
\hline & & 100 & 49,12 & \\
\hline & & 10 & 22,03 & \\
\hline & 5 & 1000 & 71,19 & \multirow{3}{*}{128,4} \\
\hline & & 100 & 45,31 & \\
\hline & & 10 & 26,15 & \\
\hline & 6 & 1000 & 80,70 & \multirow{3}{*}{93,58} \\
\hline & & 100 & 51,92 & \\
\hline & & 10 & 20 & \\
\hline
\end{tabular}

Hasil uji skrining fitokimia pada Tabel 1, menunjukkan adanya senyawa steroid dan kumarin didalam sel mikroalga T. chuii dan diketahui bahwa kedua senyawa ini lebih bersifat toksik dibandingkan dengan senyawa alkaloid, karena senyawa steroid yang berlebihan dalam tubuh memiliki efek negatif bagi makhluk hidup (16 Efek Samping Steroid, 2014).

Pada penelitian lain menyatakan bahwa ekstrak $n$-heksana dari daun pecut kuda (Stachyterpheta jamaicencis L. Vhal) yang mengandung senyawa sterol dan terpenoid bersifat toksik terhadap larva udang Artemia salina Leach dan memiliki aktifitas antikanker (Indrayani, et.al., 2006)

\subsection{Identifikasi senyawa ekstrak n-heksana dan etilasetat dengan GC-MS (Gas Chromatography- Mass Spektrometri)}

Identifikasi ekstrak n-heksana dilakukan hanya pada fraksi no 2, karena fraksi ini yang memiliki daya toksisitas tertinggi. Hasil identifikasi GC-MS yang dilakukan terrhadap fraksi no 2 ekstrak $n$ heksana terdapat 2 senyawa yaitu Phytol 2- 
Hexadecen - 1 - ol, 3,7,11,15 - tetramethyl dan 1,2 Benzenedicarboxylic acid, mono (2 - ethylhexyl) ester (Tabel 8 dan Gambar 1).

Senyawa Phytol 2-Hexadecen - 1 - ol, 3,7,11,15 tetramethyl muncul pada menit ke 15,94 dengan luas area 3,94\% dan berat molekul 296 dengan kemiripan 95\%. Phytol merupakan senyawa alkohol diterpen asiklik campuran dari bentuk cis dan trans dari Phytol 2-Hexadecen - 1 - ol, 3,7,11,15 - tetramethyl.Menurut Trianto, et al. (2004), nama lain dari senyawa ini 2-Hexadecen-1-ol, 3,7,11,15tetramethyl, l. 3,7,11,15-Tetramethyl-2-hexadecen 1-ol-, (2E, 7R, 11r), (E) -Phytol. 3,7,11,15tetramethylhexadec-2-en-1-ol dan merupakan senyawa terpenoid.Pada penelitian sebelumnya, senyawa terpenoid menunjukkan aktivitas farmakologi antara lain sebagai antiviral, antibakteri, antiinflamasi, antikanker, dan aktifitas inhibisi terhadap sintesis kolesterol. Hal ini didukung juga dengan penelitian lainnya menyatakan phytol merupakan kelas baru yang menjanjikan untuk pengobatan artiritis rheumatoid dan penyakit inflamasi (Made et.al.,2013). Struktur dari senyawa tersebut seperti terlihat pada Gambar 2.

Tabel 8.

Hasil identifikasi senyawa fraksi ekstrak n-heksana

\begin{tabular}{llllll}
\hline No & Nama Senyawa & RT & $\begin{array}{l}\% \\
\text { area }\end{array}$ & RM & $\begin{array}{l}\text { Qualit } \\
\text { y (\%) }\end{array}$ \\
\hline 1 & $\begin{array}{l}\text { Phytol } \\
\text { Hexadecen-1- } \\
\text { ol,3,7,11,15- }\end{array}$ & $\begin{array}{l}15,9 \\
\text { tetramethyl }\end{array}$ & 3,74 & $\mathrm{C}_{20} \mathrm{H}_{40} \mathrm{O}$ & 50 \\
& $\begin{array}{l}\text { Benzenedicarbox } \\
\text { ylic acid, mono }\end{array}$ & 39,7 & 94,1 & $\mathrm{C}_{16} \mathrm{H}_{22} \mathrm{O}$ & 91 \\
& $\begin{array}{l}\text { (2- } \\
\text { ethylhexyl)ester }\end{array}$ & & & & \\
& & & & \\
\hline
\end{tabular}

Abundance

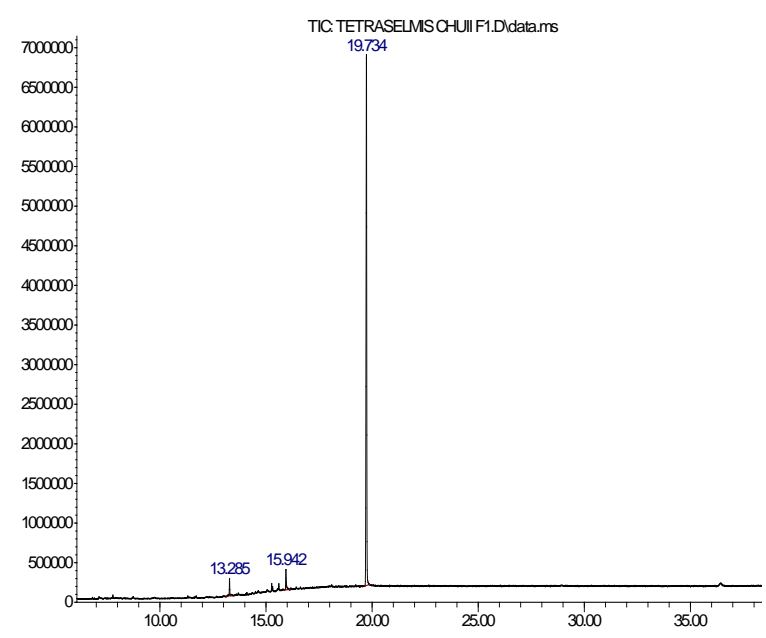

Gambar 1. Kromatogram fraksi 1 ekstrak n-heksana

Sedangkan senyawa yang kedua adalah Benzenedicarboxylic acid, mono (2 - ethylhexyl) ester muncul pada menit ke 19,73 dengan luas area $94,18 \%$ dan berat molekul 278 dengan \% kemiripan 91\%.Senyawa 1,2-benzenedicarboxylic acid, mono (2-ethylhexyl) ester mempunyai nama lain phthalic acid (mono (2-ethylhexyl) phthalate, phthalic acid mono (2-ethylhexyl) ester, 1benzenecarboxylic acid mono-octyl ester yang merupakan senyawa ester aromatic (asam dikarboksilat aromatik) atau asam lemak tak jenuh. Pada penelitian sebelumnya mengenai ekstrak Gorgonian bahwa senyawa 1,2-benzenedicarboxylic acid bersifat toksik dan dapat dikembangkan sebagai antikanker (Trianto, et.al., 2004). Berikut adalah struktur senyawa 1,2-benzenedicarboxylic acid, mono (2-ethylhexyl) ester (Gambar 3)<smiles>C/C(=C\CO)CCC[C@H](C)CCC[C@H](C)CCCC(C)C</smiles>

Gambar 2. Struktur senyawa Phytol 2-Hexadecen - 1 - ol, $3,7,11,15$ - tetramethyl

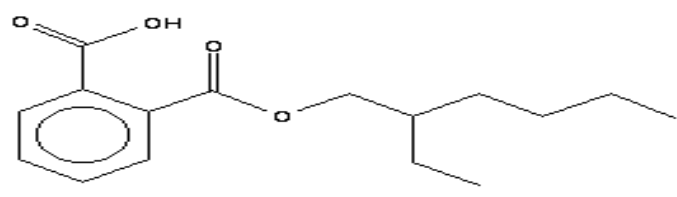

Gambar 3. Struktur senyawa 1,2-benzenedicarboxylic acid,mo(2-ethylhexyl) ester

Berdasarkan hal tersebut maka senyawa Phytol 2-Hexadecen - 1 - ol, 3,7,11,15 - dan 1,2benzenedicarboxylic acid, mono (2-ethylhexyl) esteryang terkandung didalam ekstrak $n$-heksana yang mengandung senyawa toksik terhadap larva Artemia salina Leach.

Tabel 9.

Hasil identifikasi fraksi 1 Fraksi $n$-heksana dari mikroalga $T$. chuii

\begin{tabular}{llllll}
\hline No & nama senyawa & RT & $\begin{array}{l}\% \\
\text { Area }\end{array}$ & RM & $\begin{array}{l}\text { Kualitas } \\
(\%)\end{array}$ \\
\hline 1 & $\begin{array}{l}1,2 \\
\text { Benzenedicarboxylic } \\
\text { acid, bis (2 - } \\
\text { ethylhexyl) ester }\end{array}$ & 19.73 & 97.49 & $\mathrm{C}_{24} \mathrm{H}_{38} \mathrm{O}_{4}$ & 91 \\
& & & & \\
\hline
\end{tabular}

Sedangkan hasil identifikasi untuk fraksi 1 pada ekstrak etil asetat dapat dilihat pada Tabel 9 dan pola kromatogramnya dapat dilihat pada Gambar 4 . Berdasarkan uji toksisitas terhadap fraksi etil asetat mengandung senyawa 1,2 Benzenedicarboxylic acid, bis (2 - ethylhexyl) ester. Nama lain dari senyawa tersebut adalah Phthalic acid, bis(2-ethylhexyl) ester; Bis(2-ethylhexyl) 1,2benzenedicarboxylate. 
Citation:Agustini, Ni Wayan Sri (2017) Identifikasi Senyawa Aktif dan Toksisitas Hayati Ekstrak $N$-Heksana, Etil Asetat dan Etanol Mikroalga Tetraselmis Chuii Secara Brine Shrimp Lethality Test (BSLT) Warta IHP, 34(1),8-17

Hasil peneltian pada studi ini mendukung penelitian yang dilakukan oleh Rahayu, et al., (2013), menyatakan bahwa senyawa 1,2benzenedicarboxylic acid, mono (2-ethylhexyl) ester yang terdapat pada spons Callyspongia aerizusa memiliki aktivitas sebagai antikanker. Berikut adalah struktur senyawa 1,2benzenedicarboxylic acid, bis (2-ethylhexyl) ester (Gambar 5).

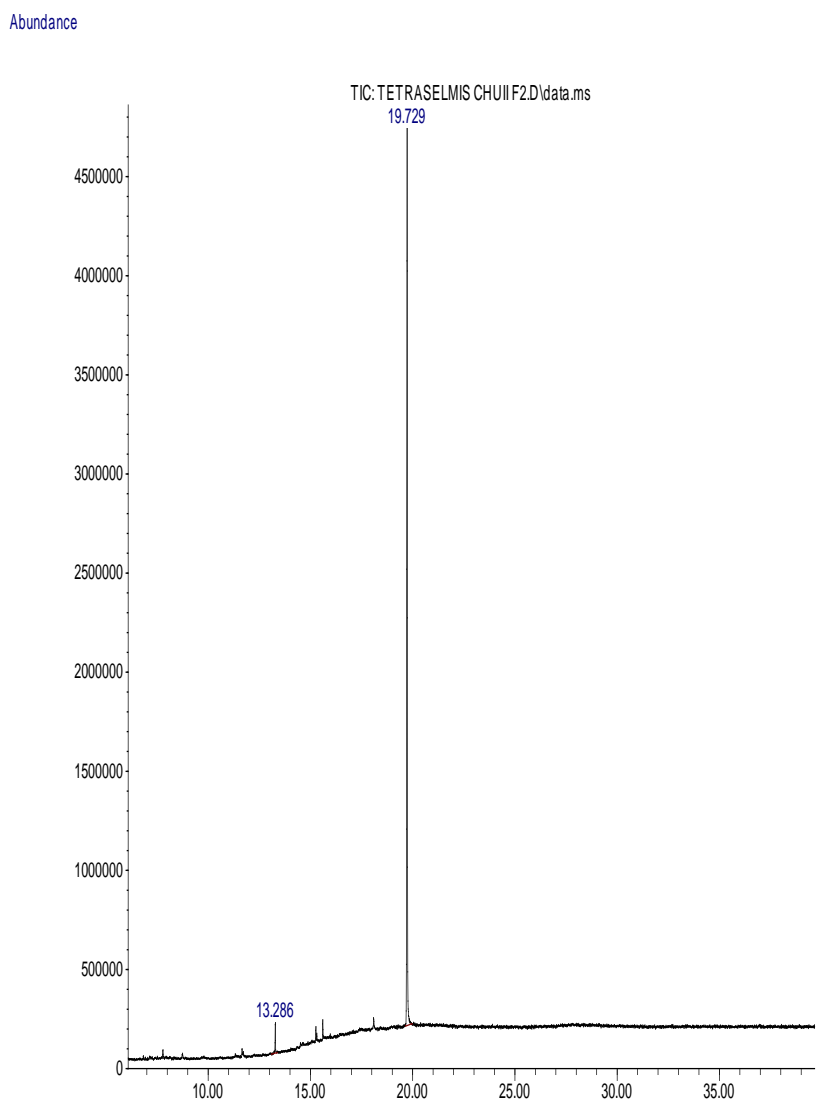

Gambar 4.Kromatogram fraksri 1 ekstrak etil asetat

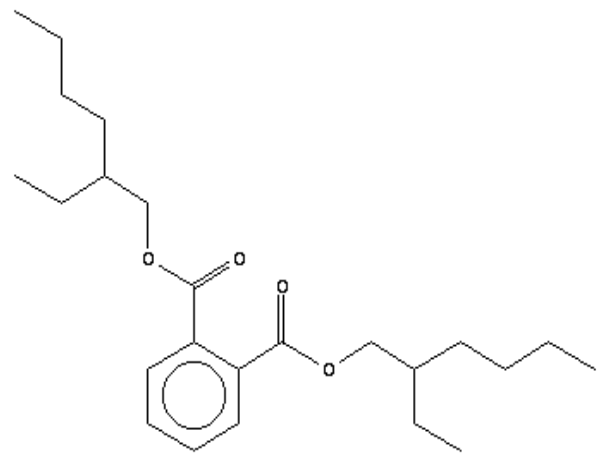

Gambar 5.Struktur senyawa 1,2 - Benzenedicarboxylic acid, bis (2 - ethylhexyl) ester
Berdasarkan hal tersebut, senyawa 1,2 Benzenedicarboxylic acid, bis (2 - ethylhexyl) ester, termasuk golongan asam lemak yang terkandung di dalam ekstrak etil asetat yang mempunyai sifat toksik terhadap larva Artemia salina Leach.

\section{KESIMPULAN}

Ekstrak $n$-heksana, etil asetat dan etanol mikroalga $T$. chuii memiliki toksisitas hayati terhadap larva udang Artemia salina Leach dengan nilai LC $_{50}$ berturut-turut sebesar 39,30 ppm;38,53 ppm ;239,12 ppm. Nilai $\mathrm{LC}_{50}$ pada hasil fraksi yang paling toksik adalah ekstrak $n$-heksana pada fraksi 2 dan ekstrak etil asetat pada fraksi 1 dengan nilai $\mathrm{LC}_{50}$ berturut-turut 32,61 ppm; 38,44 ppm.Kandungan senyawa fraksi ekstrak $n$-heksana mikroalga $T$. chuii yang aktif terhadap larva udang Artemia salina Leach adalah Phytol 2-Hexadecen - 1 - ol, 3,7,11,15 - tetramethyl dan 1,2 Benzenedicarboxylic acid, mono (2 - ethylhexyl) ester, sedangkan dari fraksi ekstrak etil asetat 1,2 Benzenedicarboxylic acid, bis (2 - ethylhexyl) ester. Berdasarkan hasil trersebut maka, T. chuii berpotensi sebagai alternatif obat baru yang bersifat alami.

\section{Daftar Pustaka}

16 Efek Samping Steroid. (2014). Reps-id.com. Retrieved February 9, 2017, from http://reps-id.com/16-efeksamping-steroid/

Isnawati, A., Mudahar, H., \& Kamilatunisah. (2008). Isolasi dan Identifikasi Senyawa Kumarin dari Tanaman Artemisia Annua (1).Media Litbang Kesehatan, XVIII(3), 107-118.

Carballo, J., Hernández, Z., Pérez, P., \& García, M. (2002). A comparison between two brine shrimp assays to detect in vitro cytotoxicity in marine natural products. $B M C$ Biotechnology, 2, 17. https://doi.org/10.1186/1472-67502-17

De Padua LSN, Bunyapraphatsana RH, Lemmens MJ. (1999).Medicinal and Poisinous Plant Research of SouthEast Asia 12. Wageningen, the Netherland :Pudoc Scientific Publisher.

Harbone, J. B. (1996).Metode Fitokimia, Penuntun Cara Modern Menganalisa Tumbuhan(Ed.2). Diterjemahkan oleh Padma, W.K., Soediro I., Bandung : ITB.

Indrayani, L., Soetjipto, H., \& Sihasale, L. (2006). Skrining fitokimia dan uji toksisitas ekstrak daun pecut kuda (Stachytarpheta jamaicensis L. Vahl) terhadap larva udang Artemia salina Leach. Journal of Biological Researches, 12(1), 57-61. https://doi.org/10.23869/bphjbr.12.1.200610

Katno. (2008). Tingkat Manfaat Kegunaan dan Efektivitas Tanaman Obat dan Obat Tradisional.Karanganyar :B2P2TOOT Badan Penelitian dan Pengembangan Kesehatan, Depkes RI.

Lednicer D. (2011).Steroid Chemistry at a Glance. Hoboken: Wiley.

Meyer, B., Ferrigni, N., Putnam, J., Jacobsen, L., Nichols, D., \& McLaughlin, J. (1982). Brine Shrimp: A Convenient General Bioassay for Active Plant Constituents. Planta Medica, 45(5), 31-34. https://doi.org/10.1055/s-2007-971236

Prasetyorini, P., Wiendarlina, I. Y., \& Peron, A. B. (2011). Toksisitas Beberapa Ekstrak Rimpang cabang Temulawak (Curcuma xanthorrhiza Roxb.) pada Larva Udang (Artemia 
Halaman | 17

salina Leach).FITOFARMAKA, 1(2), 14-21. Retrieved from https://journal.unpak.ac.id/index.php/fitofarmaka/article/ view $/ 160$

Rahayu, M. R., Sibarani, J., \& Swantara, I. M. D. (2013). Uji Toksisitas dan Identifikasi Ekstrak Etanol Spons Callyspongia aerizusa Terhadap Larva Artemia salina L .Cakra Kimia (Indonesian E-Journal of Applied Chemistry), 1(1), 1-7.

Redja IW. (1982). Dasar - dasar Analisis Kuantitatif dan Analisa Instrumen.Jakarta :Fakultas Farmasi Universitas Pancasila.

Tibbetts, S. M., Milley, J. E., \& Lall, S. P. (2015). Chemical composition and nutritional properties of freshwater and marine microalgal biomass cultured in photobioreactors.Journal of Applied Phycology, 27(3), 1109-1119. https://doi.org/10.1007/s10811-014-0428$\mathrm{x}$

Trianto, Agus., HAS, Yan Yan., Ambriyanto., Retno Muwarni (2004). Uji Toksisitas ekstrak Gorgonian Isis Hiprus Terhadap Naupilus Artemia salina. Journal Ilmu Kelautan. Universitas Diponegoro - FPIK. 9 (2), 61 - 66. 